than in water-logged confined layers, from which water would not be immediately expelled during disturbance. It is also considered likely that the directions of the convolute fold axes, which according to my mechanism depend to a large degree on the distribution of the pockets of material that had retained a notable shearing strength, would be more haphazard resulting from the liquefaction of water-covered deposits than in examples due to directed movements within confined layers.

Finally, it may be noted from the foregoing that the reasons which make Sanders' mechanism unacceptable are satisfied by the mechanism proposed by the writer. In addition, exaggeration, distortion, and overturning of primary upward protuberances, and the inversion of the filling of depositional depressions, as well as the irregular attitudes of the axial planes and directions of recumbency of the folds, can be adequately explained by laminar flow within liquefied layers, whether confined or, in the examples where unconformities developed during deformation, water-covered.

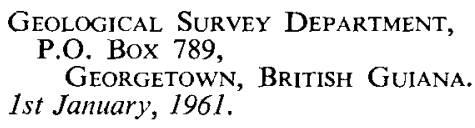

(Published by permission of the Director of the Geological Survey of British Guiana.)

\title{
THE PATTERN OF SOME PACIFIC ISLAND CHAINS
}

SIR, - The article entitled, " The Pattern of Some Pacific Island Chains," by L. J. Chubb (1957) has just reached the present author. Chubb's main hypothesis deals with the evolution of the island chains and origin of the coral reefs as follows: "Nearly all the islands discussed in this paper must have originated in pre-glacial times, so they would be expected to furnish evidence of any post-glacial rise in sea-level. But this rise would have been everywhere equal, the sea cannot have risen by different amounts around different islands, yet the degree of drowning of the coasts and the stage in the development of reefs varies from island to island within any one chain. The only explanation of this fact is that each island subsided independently, . . " (italics supplied).

The writer, during nearly two decades as District Geologist in the Hawaiian Islands and as Geologist-in-Charge of Pacific Ocean investigations for the Geological Survey, has never found any fact to substantiate Mr. Chubb's conclusion. For example, on page 222 he states, "The Hawaiian chain shows a very complete sequence but it is characterized by the absence of drowned river-yalleys and of barrier reefs, though fringing-reefs and atolls occur" (italics supplied). All of the islands where not veneered with recent lava have deeply drowned river valleys which have been described in the literature since 1935 (Stearns 1935a, 1935b, 1935c, 1946a, and Stearns and Vaksvik 1935). Logs of wells at the mouths of these valleys indicate that the subsidence amounts to more than 1,200 feet.

In the same paragraph on page 222 Chubb states: " Eastward lies Kauai, an ancient volcano so deeply dissected that all trace of its original form is lost." Kauai contains near its centre a lava filled caldera 10 miles across and although it is deeply eroded there is no difficulty in tracing its original form (Stearns 1946a, Macdonald, Davis, and Cox 1960).

On page 223 Chubb states: "The only important embayment within the chain, Pearl Harbour in Oahu, is due, not to the drowning of a river-valley, but to the depression between the two volcanoes composing the island being still below the sea. This need have involved neither subsidence of the island nor a rise of sea-level." Pearl Harbour is due to the drowning of rivervalleys (Stearns 1935a and b, and Stearns and Vaksvik 1935). The contact of the Koolau and Waianae lavas lies several miles west of Pearl Harbour.

On the same page he states that Tau, Olosenga, Ofu and Tutuila Islands in 
the Samoan chain have no recognizable craters and the Pago Pago, the one important embayment on Tutuila resembles Pearl Harbour. The harbour of Pago Pago is a drowned river-valley along a large caldera escarpment. A caldera exists on Tau. Olosega and Ofu are erosion remnants of a single volcano which had a large caldera (Stearns 1944).

On page 224 is a discussion of the Cook group in which reefs 20 to 200 feet above sea-level are cited as evidence of uplift. Although some of these reefs may be due to uplift, many of the lower ones are undoubtedly due to eustatic shifts of sea-level in Pleistocene time in common with all other island groups of the Pacific that carry reefs and shore lines above sea-level (Stearns 1938a and $b, 1941,1945 b$ ).

We are led to believe from Chubb's paper that each volcano and island chain built up above sea-level by lava flows became extinct, was then eroded and finally subsided to develop first barrier reefs and then sink beneath the waves to become an atoll. This theory, "that each island subsided independently," is not supported by the facts so far as the present writer is aware in any of the island chains. The mechanism of independent subsidence of volcanoes built along either a single or double rift zone would require highly improbably geologic processes. Ample evidence exists that the Hawaiian archipelago, which is a good example of island chains, was built over two great rift zones with a migration of the volcanic activity lengthwise along both rifts ending with Hawaii at the south-east as the youngest island. Deeply drowned valleys on all of the islands, including Hawaii, and emerged shorelines as high as 1,200 feet above sea-level, indicate that the chain as a whole has survived as a unit mass over a long period of time, at least since the Pliocene.

The rate of weathering, which proceeds rapidly in the tropics, probably has been overestimated and it is possible that the Hawaiian Islands, where weathering extends downward more than 300 feet in some of the older rocks, may well indicate that the older volcanoes became extinct in early or middle Tertiary rather than in the late Tertiary as commonly believed. The presence of atolls at the north-east end of the chain with stacks and fringing reefs to the south-east can be explained better by the downward tilting and/or greater age of the chain to the north-west; and hence more erosion for the islands on the north-west end.

On page 228 Chubb states, "Dietz and Menard (1953) have described submerged terraces at various depths from 180 to 700 fathoms around several of the islands, which they interpret as drowned shorelines, indicating subsidence. But this is difficult to reconcile with the absence of drowned river-valleys, which suggests that the lack of barrier-reefs is due to the islands not having subsided." Here again Chubb was unable to reconcile the submerged terraces and the drowned shorelines. There is no doubt that submergence in the central Pacific has been of the order of 10,000 feet (Stearns 1946b).

All of the simatic islands in the central Pacific have subsided and at the same time have been subjected to eustatic shifts of sea-level (Stearns 1946c), the later ones due chiefly to glaciation and deglaciation in the order of 600 fect, ranging from about 300 feet below present sea-level to about 300 feet above present sea-level (Fairbridge 1960), while some of the islands beyond the andesite or sialic line have emerged, uplifting and tilting the reefs on which the Pleistocene eustatic shorelines were cut. In addition to the eustatic shorelines due to changes in the volume of the ice caps there is evidence of tremendous changes in the shape of the floor of the Pacific in Tertiary and Quaternary time which have left shorelines probably eustatic up to 1,200 feet above sea-level, not due to glaciation and deglaciation (Stearns 1945a).

P.O. Box 241,

WAHIAWA,

HaWAII.

9th January, 1961. 


\section{REFERENCES}

FaIrbridge, R. W., 1960. The Changing Levels of the Sea., Sci. Amer., 202, $70-79$.

Macdonald, G. A., D. A. Davis and D. C. Cox, 1960. Geology and GroundWater Resources of the Island of Kauai, Hawaii, Haw. Div. of Hydrography Bull. 13, 1-209.

Stearns, H. T., 1935a, The Geologic History of Oahu (Hawaiian Islands), (Abst.), Wash. Acad. Sci. Journ., 25, 89-90.

1935b, Shore Benches on the Island of Oahu, Hawaii, Geol. Soc. Amer. Bull., 46, 1467-1482.

$1935 \mathrm{c}$, Pleistocene Shore Lines on the Island of Oahu and Maui, Hawaii, Geol. Soc. Amer. Bull., 46, 1927-1956.

1938a, Ancient Shore Lines on the Island of Lanai, Hawaii, Geol. Soc. Amer. Bull., 49, 615-628.

1938b, Shore Benches on the Island of Guam, Marianas Islands, (Abst.) Geol. Soc. Amer. Proc., 1937, 116-117.

1941, Shore Benches on North Pacific Islands, Geol. Soc. Amer. Bull., 52, $773-80$.

1944, Geology of the Samoan Islands, Geol. Soc. Amer. Bull., 55, 1279-1332.

1945a, Eustatic Shore Lines in the Pacific, Geol. Soc. Amer. Bull., 56, $1071-1078$.

1945b, Decadent Coral Reef on Eniwetok Island, Marshall Group, Geol. Soc. Amer. Bull., 56, 783-8.

1946a, Geology of the Hawaiian Islands, Haw. Div. of Hydrography Bull., 8, 1-102.

1946b, Late Geologic History of the Pacific Basin, Amer. Journ. Sci., 243, 614-26.

1946c, An Integration of Coral-Reef Hypotheses, Amer. Journ. Sci., 244, 245-62.

and K. N. VAKsVIK, 1935, Geology and Ground-Water Resources of the Island of Oahu, Hawaii, Haw. Div. of Hydrography Bull., 1, $1-469$.

\section{IRISH EROSION SURFACES}

SiR,-CMr. E. H. Thornton has recently (1960) offered a statistician's comments on a published summary (Davies, 1958) of a paper on Irish erosion surfaces which $I$ read to Section $E$ of the British Association in 1957. Mr. Thornton reaches the conclusions, first that in the altimetric frequency graphs which formed the basis of my work the occurrence of peaks may be attributed largely to chance and that they do not therefore represent erosion surfaces, and secondly that the coincidence of peaks in the graphs for various counties is of little or no significance. The present writer himself confessed in reading the original paper to having some doubts as to the value of the statistical results, but the final verdict on their validity must obviously come from the comparison of the statistical results with the data obtained by the extensive field-mapping of erosion surfaces. It will clearly be many years before erosion surfaces have been mapped over a sufficiently large area of Ireland for such a full comparison to be made, but during the last three years morphological mapping has been carried out by the present writer over more than 1,000 sq. miles of south-eastern Ireland and has included some 700 sq. miles within Counties Wexford and Wicklow, both of which counties were included in the statistical analysis. A full interpretation of the mapped features has yet to be made, and in any case as neither Co. Wexford nor Co. Wicklow has been completely mapped it would be unreasonable to try to compare the results of the mapping so far carried out with the frequency graphs constructed by using all the trigonometrical points in each county. The mapping has, however, demonstrated that flats of apparent erosional origin are widespread in the two counties, and from the work carried out so 